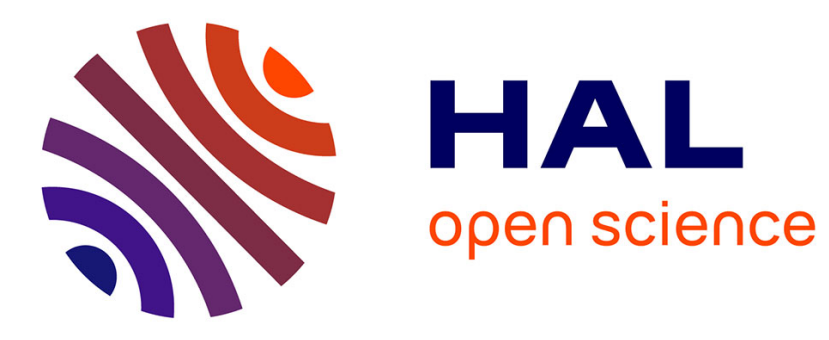

\title{
Tracking archaeological and historical mines using mineral prospectivity mapping.
}

\author{
Fabrice Monna, Estelle Camizuli, R. Nedjai, Florence Cattin, Christophe \\ Petit, Jean-Paul Guillaumet, Isabelle Jouffroy-Bapicot, Benjamin Bohard, \\ Carmela Chateau, Paul Alibert
}

\section{To cite this version:}

Fabrice Monna, Estelle Camizuli, R. Nedjai, Florence Cattin, Christophe Petit, et al.. Tracking archaeological and historical mines using mineral prospectivity mapping.. Journal of Archaeological Science, 2014, 49, pp.57-69. 10.1016/j.jas.2014.04.022 . hal-01002800

\section{HAL Id: hal-01002800 https://hal.science/hal-01002800}

Submitted on 4 May 2020

HAL is a multi-disciplinary open access archive for the deposit and dissemination of scientific research documents, whether they are published or not. The documents may come from teaching and research institutions in France or abroad, or from public or private research centers.
L'archive ouverte pluridisciplinaire HAL, est destinée au dépôt et à la diffusion de documents scientifiques de niveau recherche, publiés ou non, émanant des établissements d'enseignement et de recherche français ou étrangers, des laboratoires publics ou privés. 


\title{
Tracking archaeological and historical mines using mineral prospectivity mapping
}

\author{
F. Monna ${ }^{\mathrm{a}, *}$, E. Camizuli ${ }^{\mathrm{a}}$, R. Nedjai ${ }^{\mathrm{b}}$, F. Cattin ${ }^{\mathrm{a}}$, C. Petit $^{\mathrm{c}}$, J.-P. Guillaumet $^{\mathrm{a}}$, \\ I. Jouffroy-Bapicot ${ }^{\mathrm{d}}$, B. Bohard ${ }^{\mathrm{a}}$, C. Chateau $^{\mathrm{e}}$, P. Alibert ${ }^{\mathrm{f}}$ \\ a ARTéHIS, UMR 6298 CNRS-Université de Bourgogne, Batiment Gabriel, boulevard Gabriel, F-21000 Dijon, France \\ ${ }^{\mathrm{b}}$ Institut de Géographie Alpine, UMR CNRS-Université de Grenoble, 14 bis avenue M. Reynoard, F-38100 Grenoble, France \\ ${ }^{\mathrm{C}}$ ARSCAN, UMR 7041-Université Paris 1 Panthéon-Sorbonne, 3 rue Michelet, F-75006 Paris, France \\ ${ }^{\mathrm{d}}$ Chrono-Environnement, UMR 6249 CNRS-Université de Franche-Comté, 16 route de Gray, F-25030 Besançon Cedex, France \\ e Université de Bourgogne, UFR SVTE, Bat. Gabriel, F-21000 Dijon, France \\ ${ }^{\mathrm{f}}$ Biogéosciences, UMR 6282, CNRS-Université de Bourgogne, Bat. Gabriel, F-21000 Dijon, France
}

\section{A R T I C L E I N F O}

\section{Article history:}

Received 21 June 2013

Received in revised form

11 April 2014

Accepted 25 April 2014

Available online xxx

\section{Keywords:}

Prospection

Archaeology

Streambed sediment

Geochemical landscape

Exploratory data analysis

Fractal model

Mines

Geographical information system

\begin{abstract}
A B S T R A C T
The present study proposes a technological transfer from modern mining prospection to the field of archaeology, providing a methodology to facilitate the discovery of ancient mining sites. This method takes advantage of the thousands of geochemical analyses of streambed sediments, performed by national geological surveys to inventory mineral substances. In order to delineate geochemical anomalies, the datasets are treated following two different approaches: Exploratory Data Analysis and a fractalbased method often recognised as more powerful. Mineral prospectivity maps are then obtained by combining the results with a geographical information system. The surroundings of the Celtic oppidum of Bibracte, French Massif Central, known to have been mined at least since the Late Bronze Age until Modern Times, have been chosen to exemplify the method's potential in archaeology. First, an exhaustive record of the mining sites was undertaken over a pilot area by pedestrian prospection. If mineral prospectivity maps had been used as guidelines, $\sim 70 \%$ of these mines would have been discovered by prospecting only $\sim 15-20 \%$ of the whole area whatever the method used to treat the dataset. At least for our specific case, the multifractal approach is as powerful as EDA. Besides saving a significant amount of time and effort, the methods described here may supply clues for determining the nature of mineral substances exploited in the past, when such information cannot be straightforwardly obtained from the field or from textual archives. It should however be noticed that this approach is proposed as a first step before peer archaeological investigation following more conventional methods. Technically, there is no real obstacle to the application of the methodology proposed here, because $(i)$ software and associated packages are freely available from the web, as well as original geochemical datasets (at least in France), and (ii) minimal mathematical skills are required.(
\end{abstract}

\section{Introduction}

Ore mining has played an important role in the socio-economic history of Western Europe, from the Metal Ages through the Roman Period to medieval times (e.g. Tylecotte, 1987; Healy, 1978). Archaeometallurgical studies provide evidence for the reconstruction of past interaction networks related to ore mining. Three main categories of archaeological evidence are generally explored in the

\footnotetext{
* Corresponding author. Tel.: +33 (0)3 80396 360; fax: +33 (0)3 80396387.

E-mail address: Fabrice.Monna@u-bourgogne.fr (F. Monna).
}

study of the mining and metallurgy of past societies over space and time: related to the consumers, the producers, and the miners. Hearths, furnaces, crucibles, slags, etc. help to trace back the technology and potential transfers among the artisans-metallurgists and the smelters, from one area to another. Concerning miners, the documentation tends to show that although numerous ore bodies are present in Western Europe, only a few contain traces of early exploitation (Ambert, 1995; Barge et al., 1998; Carozza et al., 2011). This lack of evidence might suggest that only a few production centres provided metal to all consumers through a complex distribution network. There is therefore a need to create a detailed inventory, mapping early mining history. Such an inventory could 
improve our understanding of the interactions between the actors of the chaîne opératoire (Schibler et al., 2011).

In this study, we propose a technological transfer from modern mining prospection to the field of the archaeology, to provide a methodology which could assist archaeologists in discovering ancient mining sites more easily. Finding areas with high mining potential is precisely the challenge of the modern mining prospector. One objective is to delineate geochemical anomalies from the background to target more specifically the areas where mineral substances are abundant in order to optimise costly field campaigns (Carranza, 2011). Performing geochemical surveys based on streambed sediments fulfils this purpose (e.g. Garrett et al., 2008 for a historical review). The underlying idea is that stream sediments represent composite erosion products of terrains outcropping in the catchment area. Their analysis may lead to the discovery of positive geochemical anomalies. Provided their origin does not derive from modern urban or industrial effluents, such anomalies may reveal the presence of metalliferous mineralisation located upstream, within the drainage basin (a review can be found in Carranza, 2009). Many statistical techniques for determining geochemical thresholds between anomalies and background have been developed since the 1960s. Originally, elemental concentrations were assumed to follow normal distributions, and outliers were identified by basic statistics. Today, this approach is known to be mostly incorrect (Reimann et al., 2005). Later, Tukey (1977) developed a more efficient, although still basic, procedure named Exploratory Data Analysis (EDA). During the last decade, more sophisticated fractal-based models have been increasingly used (e.g. Cheng et al., 1994; Cicchella et al., 2008; Deng et al., 2010; Wang et al., 2011 for specific use in mineral prospection, and Brown and Witschey, 2003; Brown et al., 2005, for applications in spatial analysis of archaeological data). Until now, to our knowledge, the EDA and fractal-based methodologies, which are successfully and routinely used by mining companies, have never been applied to mining archaeology. We argue, nonetheless, that these methods can be adapted to reduce the area to be prospected by archaeologists.

The northeastern part of the French Massif Central - namely the Morvan - is chosen here to exemplify the potential of these methods for archaeology. Located in the centre of Morvan, the Bibracte oppidum, capital of the Aeduans during the Iron Age, and described by Caesar in "De Bello Gallico" (translation by Constant, 1990) as one of the greatest and richest oppida of Gaul, might have drawn its wealth from local ore mining (Guillaumet et al., 2001). Recent palaeoenvironmental studies have suggested that mineral resources, which are abundant in the region, may well have attracted populations as early as the Middle Bronze Age (Monna et al., 2004; Jouffroy-Bapicot et al., 2007). An archaeological excavation has demonstrated the presence of ore mining at one site located inside the oppidum walls, but the nature of the ore mined was undetermined (Cauuet and Boussicault, 2006). Currently, one of the main challenges consists in identifying and then evaluating the chronology and the magnitude of past mining, given that most of the exploitations operating in ancient times may have been masked or partially destroyed by successive posterior works. Some small ore bodies may have experienced a single phase of mining, but larger and richer deposits often document a series of works over multiple phases. In such a context, untangling the overlapping works is a difficult task. In addition, many known mines are situated at medium/high altitudes, in locations where archaeological surveys are less frequent.

The procedure proposed here combines modern techniques (including geographic information systems, statistics and mathematical modelling) and a more traditional approach (pedestrian prospection, data collection from the field or from textual archives).
The premise is to use the huge amount of geochemical data, previously obtained from streambed sediments by the French geological survey (BRGM), and to treat them by EDA (Exploratory Data Analysis) and by fractal-based techniques, so as to build mineral prospectivity maps. The degree of predictability of these two approaches is first evaluated on a pilot area, where systematic pedestrian prospection has been undertaken, to provide a control framework. Once the best approach for our purpose has been identified, the second step consists in assessing the possibilities of extension over a wider area, to recognise specific zones which should be the first targeted by any further archaeological prospection.

\section{Study area}

The Morvan massif is located in the northeastern part of the Massif Central, France (Fig. 1a). It is a middle altitude massif (max. = $901 \mathrm{~m}$ asl, Fig. $1 \mathrm{~b}-\mathrm{c}$ ). The climate is characterised by rainfalls reaching $1600 \mathrm{~mm}$ per year on the summits. Spring comes late; summer is hot, but short. Mean annual temperature is around $10{ }^{\circ} \mathrm{C}$. Industries are scarce, and the local economy is mainly centred on forestry, cattle breeding and the tertiary sector (Sirugue, 2008). Since 1970, most of the Morvan massif has been a protected area, known as the Morvan Regional Natural Park, MRNP (Fig. 1). The park covers a territory of $1730 \mathrm{~km}^{2}$, for a total population barely above 50,000 inhabitants (only one town has more than 2600 inhabitants, Fig. 1d). The area covered by the present study fits approximately the boundaries of the park. Geologically, the massif is mainly composed of Hercynian granites, intruding sedimentary, volcano-sedimentary and volcanic rocks (Delfour et al., 1991; Gourault, 1999). The whole area is crosscut by leucogranites, numerous microgranite dykes and granophyre sills. Explosive magmatic phases occurring during the Stephanian and the Permian also produced rhyolitic lavas. During the Permian, a large depression was filled by sedimentary materials of detrital origin. During the Mezosoic, sedimentary rocks covered previous formations discordantly. The Morvan is a horst, limited by large faults of regional extension. Fig. 1d depicts simplified lithological units established by the BRGM (http://geoservices.brgm.fr/ geologie): granite, basalt, gneiss, sandstone, limestone, sand, and clay. Compressive and extensive episodes, which occurred between the Autunian and the Miocene, have produced a dense fault network, most of the time filled by quartz veins. Three main types of mineral deposits have been recognised and exploited: (i) the hydrothermal mineralised quartz veins, typically with $\mathrm{U}, \mathrm{F}-\mathrm{Ba}, \mathrm{Pb}-$ $\mathrm{Zn}-\mathrm{Ag}$, or $\mathrm{Sn}-\mathrm{W}$, (ii) polymetallic mineralisation with pyrite in association with metallic sulphides, and (iii) stratiform F-Ba ore deposits in Triassic and Liassic formations (Gourault, 1999). The most recent mining exploitations focussing on $\mathrm{F}$ and Ba finally ceased during the second half of the 20th century.

Except for the 19th and 20th centuries AD, the temporal framework of the mining activities in the region is only partly known. The few metallurgical vestiges (slags or furnaces) are mainly associated with iron smelting. In any case, their scarcity suggests small-scale production. Slags including charcoals were found at the Corseries, ca. $10 \mathrm{~km}$ west of Bibracte, and at the sites of La Combe des Vaux, Bois Jobard, La Combe du Four, and Les Grands Champs, located between 20 and $40 \mathrm{~km}$ outside and north of the pilot area (Table 1). One radiocarbon analysis yields a medieval date between the 11 th and the 12 th centuries AD. The others provide dates between the 2nd and 6th centuries $A D$, corresponding to Antiquity and the First Medieval Age, but long after the Aeduan occupation. At les Corseries, however, massive dumps are crossed by a Gallo-Roman road (Gourault et al., 2012). A Celtic medal has been found nearby, in a former mining gallery, now collapsed 

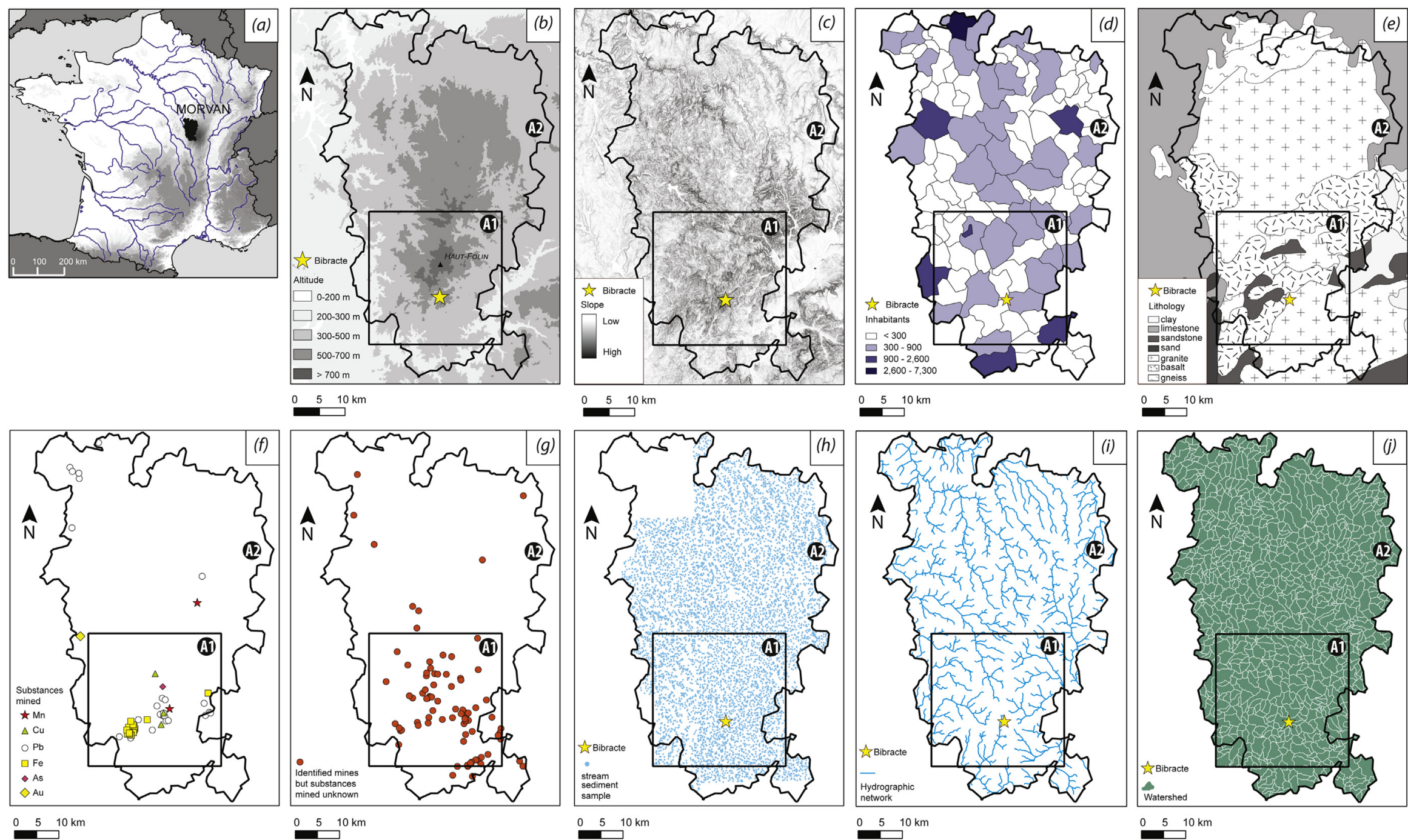

Fig. 1. (a) Location of the Morvan in France; (b) digitised elevation model; (c) map of slope; (d) population for each of the 117 communes in the Morvan Regional Natural Park; (e) lithological map; (f) map of the mining sites for which

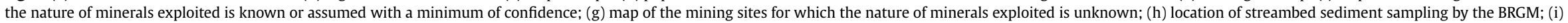
hydrographical network drawn from the DEM; and (j) reconstructed sub-watersheds. Z1 corresponds to the limits of the pilot area and Z2 to the Morvan Regional Natural Park. 
Table 1

Radiocarbon dating of charcoal trapped in slags. Type of object dated, location, uncalibrated date, and calibrated dates (using Oxcal 3.10, Bronk Ramsey, 2001) with ranges corresponding to an uncertainty of $95 \%$.

\begin{tabular}{lcc}
\hline Location & ${ }^{14} \mathrm{C} \mathrm{BP}$ & Calibrated dates \\
\hline Corseries-Sud & $1785 \pm 30 \mathrm{BP}$ & $130-340 \mathrm{AD}$ \\
Corseries-Sud & $1670 \pm 30 \mathrm{BP}$ & $262-426 \mathrm{AD}$ \\
Combe des Vaux & $1685 \pm 30 \mathrm{BP}$ & $258-420 \mathrm{AD}$ \\
Bois Jobard-Est & $1565 \pm 30 \mathrm{BP}$ & $421-564 \mathrm{AD}$ \\
Bois Jobard-Est & $1545 \pm 30 \mathrm{BP}$ & $428-583 \mathrm{AD}$ \\
La Combe du Four & $1560 \pm 30 \mathrm{BP}$ & $423-567 \mathrm{AD}$ \\
Les Grands Champs & $970 \pm 30 \mathrm{BP}$ & $1017-1154 \mathrm{AD}$ \\
\hline
\end{tabular}

(Charleuf, 1867). Moreover, a mining trench recently excavated by Cauuet and Boussicault (2006) at Bibracte seems to extend underneath the walls of the oppidum. It is filled by material dating from the 1 st century BC. All these clues unambiguously demonstrate local metal exploitation during the Aeduan occupation, despite the absence of radiocarbon dates for the Celtic period. This is in good agreement with previous environmental studies, which already suggest local mining in Prehistoric times on the basis of the amount of metals deriving from mining and/or metallurgy, atmospherically deposited in peat bogs situated nearby (Monna et al., 2004; Jouffroy-Bapicot et al., 2007; Forel, 2009). First, an area of $900 \mathrm{~km}^{2}$ located in the southern part of the MRNP (area 1: A1 in Fig. 1b), encompassing almost all the geological units found within the Morvan massif, was selected as a pilot territory. It is mostly forested, and centred on the Mont Beuvray, where the oppidum of Bibracte was located. After this pilot study, calculations were extended to the entire MRNP (area 2: A2 in Fig. 1b).

\section{Materials and methods}

\subsection{Archaeological prospection}

A pedestrian prospection campaign was systematically undertaken over the $30 \times 30 \mathrm{~km}^{2}$ pilot area to obtain the most exhaustive possible inventory of the zones where mining and metallurgical activities have taken place (Tamas, 2004; Gourault, 2009). It was mainly carried out in winter because the limited presence of vegetation facilitated the identification of potential zones of interest. Each discovery was geo-referenced using a GPS device (Fig. 1f$\mathrm{g}$, see also the database provided as Supplementary Material). The presence of dumps, platforms, or other work remains was systematically recorded. Some of the most representative remains were studied in greater detail by establishing a microtopographic record of their profiles.

\subsection{Mineralogical data}

The nature of mineral substances formerly exploited was obtained from textual sources when available (see Delfour et al., 1991; Gourault, 1999, 2009; Gourault et al., 2012; Tamas, 2004 and references cited therein for details about sources). Otherwise, samples from past exploitation tailings or outcrops were collected. Whenever possible, mineralogical species were identified using a binocular microscope and the nature of the exploitation was hypothesised.

\subsection{Geochemical data}

From 1975 to 1985 , the BRGM performed a comprehensive inventory of mineral substances over the whole French territory, and more particularly in the Massif Central (Lambert, 2005). The national stream sediment sampling campaign led to the collection of 7080 samples within the boundaries of the MRNP. The extreme north-western part of the park was not sampled (Fig. 1h). Within the pilot area alone, 2581 samples were collected, resulting in a sampling density greater than 2 samples per $\mathrm{km}^{2}$. The streambed sediments were sieved at $125 \mu \mathrm{m}$ and dried. They were measured by direct current plasma for elemental compositions (more than 22 elements were determined, including $\mathrm{Pb}, \mathrm{Zn}, \mathrm{Cu}, \mathrm{As}, \mathrm{Fe}$ and $\mathrm{Mn}$; the last two expressed as oxides). The entire dataset, together with complementary information about the sampling and analytical techniques used, is freely accessible at: http://sigminesfrance.brgm. fr, "Géochimie Inventaire BRGM" database.

\subsection{Geochemical landscapes: treatment and mapping}

A 25 m-resolution digital elevation model (without holes) was obtained from the Institut National de l'Information Géographique et Forestière (downloadable at http://professionnels.ign.fr/bdalti). The sub-watersheds and river network of the Morvan (Fig. 1i) were reconstructed using the functions contained in the GRASS module of the Quantum GIS 1.8.0. free software (http://www.qgis.org). A minimum size of 40 cells was set for each basin, providing a total of 332 drainage basins for the pilot area and 1103 units for the whole MRNP, as depicted in Fig. 1j. Such fine-tuning ensures that the vast majority of the basins contained at least one sediment sample.

\subsection{Finding anomalies}

\subsubsection{Exploratory data analysis}

In geochemical prospection, the point is to determine thresholds allowing anomalies to be delineated from the local geochemical background, which is often difficult to define (Reimann and Garrett, 2005). Several procedures have been developed to accomplish this essential and far from trivial step. One of them, namely the EDA approach developed by Tukey (1977), is statistically robust to the presence of outliers and analytical errors. It consists in a set of descriptive statistics combined to graphical tools used to perceive the structure of the data (details can be found in Carranza, 2009). In our case, a preparation of data is nonetheless needed. First, as only 26 samples were collected in the clay, 21 in the limestone, and 4 in the sand unit, these samples were excluded from further analysis. A transformation procedure was also applied to the remaining geochemical data, before computing thresholds by EDA, to make comparable the remaining samples, which come from different lithologic units: granite, basalt and gneiss (Yusta et al., 1998):

$Z_{i, j}=\frac{X_{i, j}-\operatorname{med}_{i, j}}{\mathrm{MAD}_{i, j}}$,

where $Z_{i, j}$ represents the standardised data values for the element $i$ of the lithology $j$. The $\mathrm{MAD}_{j}$, namely Median Absolute Deviation, is somewhat equivalent to the standard deviation (Tukey, 1977), and is defined as $\mathrm{MAD}_{i, j}=\operatorname{med}\left[\left|X_{i, j}-\operatorname{med}\left(X_{i, j}\right)\right|\right]$, where med represents the median. With such a transformation, however, half the values are negative and cannot be log-transformed, as recommended by Reimann et al. (2008) for strongly skewed data. That is why another transformation was performed to make all values greater or equal to 1 :

$z_{i, j}=1+Z_{i, j}-\min \left(Z_{i, j}\right)$

Uni-element geochemical data, except iron, were then logtransformed and pooled to produce $z_{\text {pooled }}(i)$. At that point, it is noteworthy to mention that the magnitude of the $z_{\text {pooled }}(i)$ data is 
expected to be controlled by the presence of metalliferous mineralisation located upstream, but also by downstream dilution due to the mixing of various (not anomalous) sources of stream sediments. Such a dilution phenomenon may somehow obscure the detection of anomalous sources. Correction procedures have been developed (e.g. Bonham-Carter and Goodfellow, 1986; Carranza and Hale, 1997), but they were not applied here as the constructed watersheds are large enough to get rid of most of the problems due to dilution. Operated on the $z_{\text {pooled }}(i)$ data calculated as described above, the Tukey approach allows defining the median (quartile Q2), the lower hinge (LH, quartile Q1), the upper hinge (UH, quartile $\mathrm{Q} 3$ ), as well as the hinge width (HW, also called interquartile range IQR, defined as Q3-Q1) (Fig. 2). The lower and upper inner fences, LIF and UIF respectively, are the first boundaries beyond which observations are considered as outliers. They are defined as $\mathrm{LIF}=\mathrm{LH}-(1.5 \times \mathrm{HW})$ and $\mathrm{UIF}=\mathrm{UH}+(1.5 \times \mathrm{HW})$. Two other boundaries, the lower and upper outer fences, LOF and UOF, respectively, are used to define extreme outliers: $\mathrm{LOF}=\mathrm{LH}-(3 \times \mathrm{HW})$ and $\mathrm{UOF}=\mathrm{UH}+(3 \times \mathrm{HW})$. Traditionally, the minimum and maximum values inside the inner fences may also be represented as upper and lower whiskers (UW and LW, respectively $): \mathrm{UW}=\max (X[X<\mathrm{UIF}])$; $\mathrm{LW}=\min (X[X>\mathrm{LIF}])$. For EDA-based mapping, data are divided into 7 groups: $(i)$ from Min to LOF, for extremely low background, (ii) from LOF to LIF, for low background, (iii) from LIF to Q1, (iv) from Q1 to Q3, for the middle $50 \%$, ( v) from Q3 to UIF, (vi) from UIF to UOF, for near (high) outliers, and (vii) from UOF to Max, for extreme outliers (Fig. 2). In practice, the 6 thresholds used as limits for the 7 groups were calculated with the map.eda7 function of the rgr package (Garrett, 2013), supplementing the free R software (http://www.rproject.org). The $z_{\text {pooled }}(i)$ data were used as inputs, as defined above.

\subsubsection{Fractal-based approach to geochemical landscapes}

Briefly, the fractal approach consists in an improvement with respect to the empirically-driven exploratory analysis of geochemical anomalies described above, as it integrates the spatial correlation of geochemical data and the scaleindependent features of geochemical landscapes (Cheng et al., 1994; Cheng, 1999). Fractal models are based on the fact that geochemical distribution patterns result from numerous geological processes, which have taken place at different rates, and different temporal and geographical scales. Interestingly, the resulting geochemical landscape may be viewed as an object presenting a fractal dimension (Cheng et al., 1994, 1996; Carranza, 2009). Many fractal models exist, such as numbersize, perimeter-area, concentration-distance, or power spectrum area (Li et al., 2003; Hassani et al., 2009). The concentration-area model (C-A model) developed by Cheng et al. (1994) was selected for the present study, as it is one of the most widely used in mineral prospection. Basically, a map of the element of interest is produced by interpolating the point data using an Akima interpolation algorithm (Akima, 1970). Contours of concentration $r_{i}$ are computed and their respective areas, $A_{i}\left(r>r_{i}\right)$, where $r$ is greater than $r_{i}$, are calculated. Paired $r_{i}$ and $A_{i}$ values should theoretically satisfy a power-law relation:

$A_{i}\left(r>r_{i}\right)=c r_{i}^{-D}$

where $c$ is a constant and $D$, the fractal dimension for the $\mathrm{C}-\mathrm{A}$ model. Plotted on a $\log A_{i} v s \log r_{i}$ diagram, the set of points $\left(r_{i}, A_{i}\right)$ may define either one straight line, indicating a single fractal dimension $D$, or several segments, involving a multifractal model. In this latter case, the breaks (or inflection points) in slope limiting different populations can be used as cut-off points to separate background and anomaly concentration values into two or more distinct categories. In practice, the caplot function of the rgr package for $\mathrm{R}$ was used to compute the concentration-area plot. Note that an equivalent function (concarea) exists in the StatDA package (Reimann et al., 2008). The data were first logtransformed, then an Akima interpolation (over a grid of $100 \times 100$, default values) was applied. After inspection of the shape of the $\mathrm{C}-\mathrm{A}$ plot, two or more straight lines, fitted by ordinary least square regression, were defined over the plot (see Cheng et al., 1996). Thresholds correspond to slope changes.

\subsubsection{Prospectivity maps}

For both EDA and fractal-based approaches, the drainage basins were coloured to highlight the following positive categories: high background, low anomaly and high anomaly. A basin generally contains several samples, so a choice had to be made concerning the value affected to each of the individual basins (and hence its category and corresponding colour). A straightforward approach would be to compute the arithmetic mean or the median, and to categorise the basin according to one of these values. In that case, the presence of samples, with high metal concentrations (i.e. outliers, which possibly indicate a mine or an ore deposit), might well be overlooked, especially if the median known to be robust to exceptionally high values is computed. That is why the individual displaying the highest concentration was used for categorising the whole drainage basin. Such an approach reduces the risk of false negative errors, but might possibly be less efficient. A greater land surface will probably have to be prospected to find any traces of mining, as more basins will be assumed to have good prospectivity potential. In the worst case, prospection will be undertaken in sterile areas. Mapping and subsequent calculation used the open source software Quantum GIS.

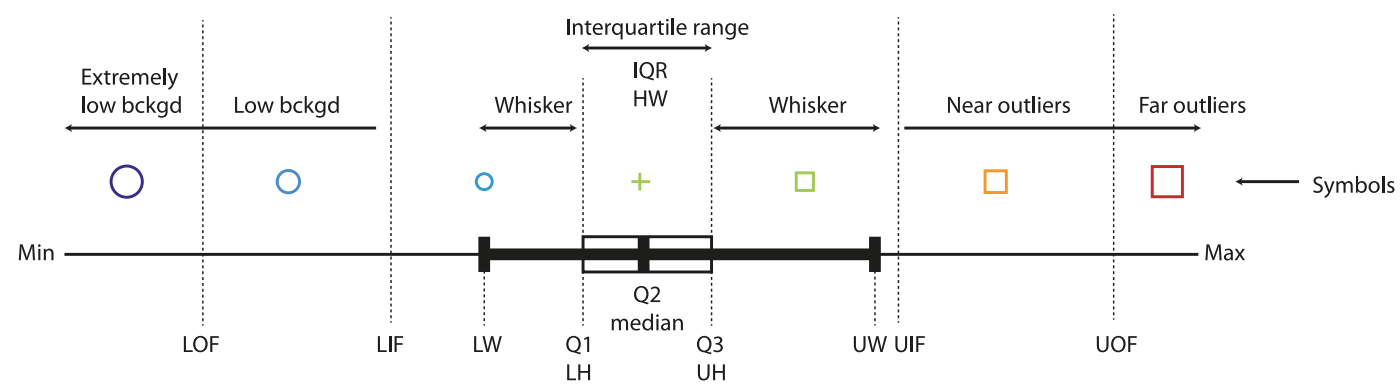

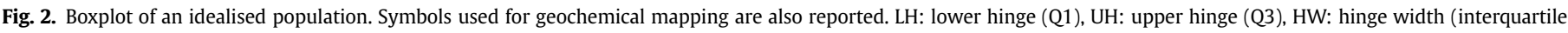
range IQR), LIF: lower inner fence, LOF: lower outer fence, UIF: upper inner fence, UOF: upper outer fences, UW: upper whisker, LW: lower whisker. 
(a)
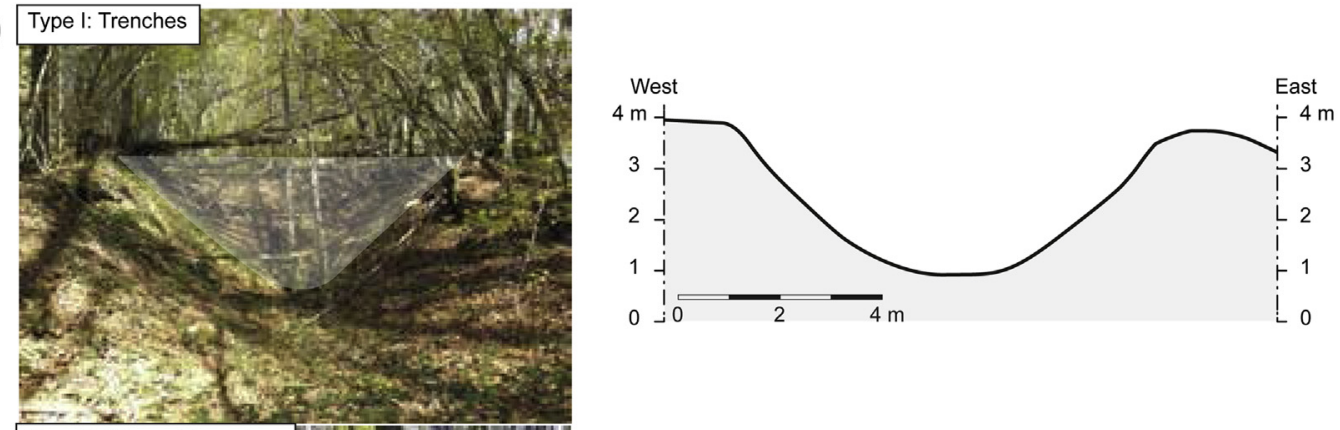

(b)

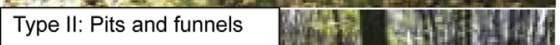

(c)
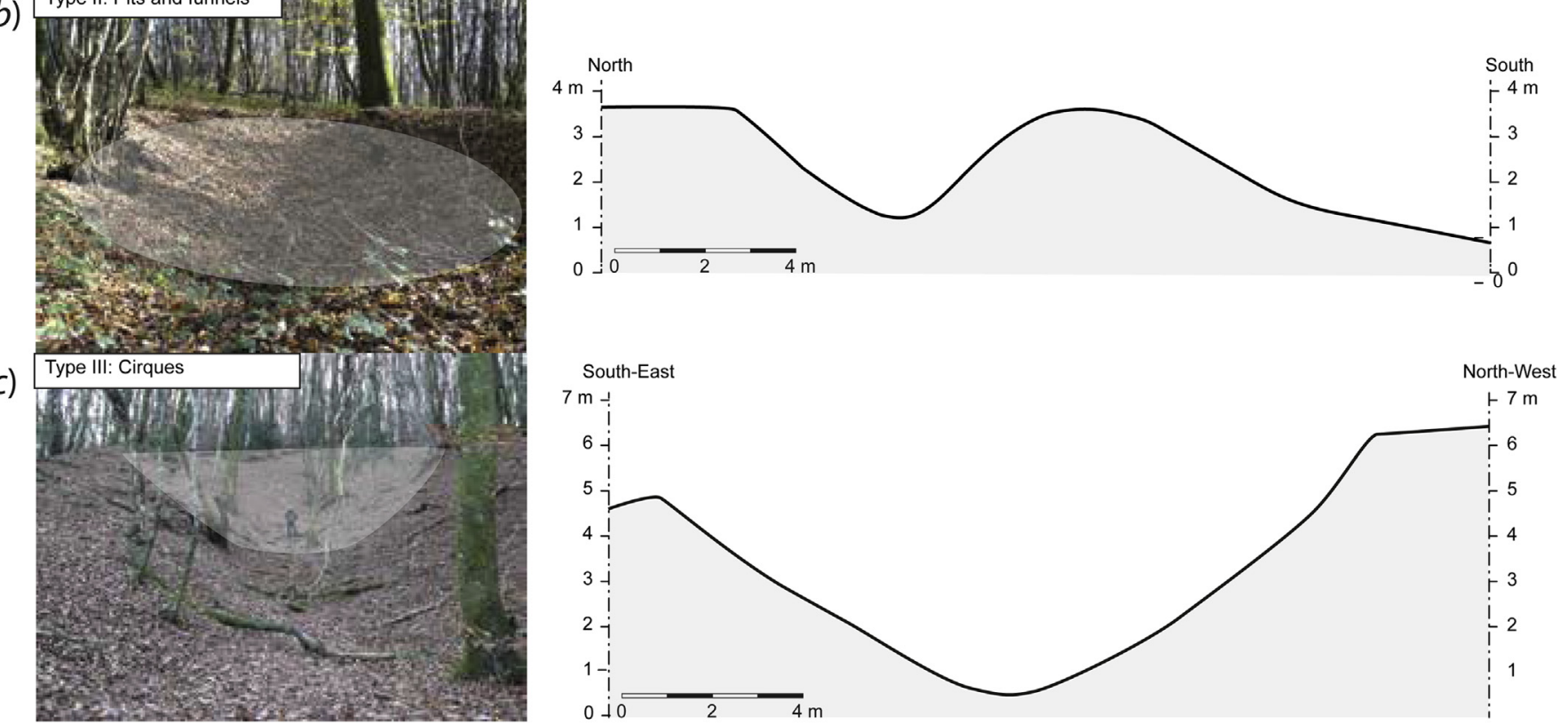

Fig. 3. Typology of mining structures. (a) trenches, (b) pits and funnels, and (c): cirques. The corresponding topographical profiles are shown next to the photographs.

\section{Results and discussion}

\subsection{Spatial distribution and types of extraction works}

A total of 109 mining sites was identified over the $30 \times 30 \mathrm{~km}^{2}$ pilot area (Fig. 1e-f, see Supplementary materials for details), excluding the mines exploited for $\mathrm{U}$, $\mathrm{F}$ or $\mathrm{Ba}$, which present no interest from an archaeological perspective. Their spatial distribution is slightly but significantly clustered (Nearest Neighbour Index $=0.76, p<0.01$ ), because faults and fractures, together with lithology, mainly control their presence (Gourault, 1999). Three types of structures are present at these mining sites (Fig. 3). Trenches often follow mineralised veins ( $n=110$, Fig. 3a). Their depth ranges from 2 to $15 \mathrm{~m}$, while their length ranges from about $20 \mathrm{~m}$ to $800 \mathrm{~m}$ and follows a log-normal distribution, indicating a majority of short trenches (Fig. 4a). Most of them possess a NNWSSE orientation (Fig. 4b). Pits and funnels (ca. 3-15 m of diameter) are generally adjacent to the trenches (Fig. 3b). They could correspond to small shafts partially filled, or prospection works undertaken before extending the exploitation. Cirques are also present, sporadically ( $n=15$, Fig. $3 c$ ). All three types can be found together at the same mining site, and mine-clearings often hem the structures. Hydraulic management works, such as channels, reservoirs or embanking, were also frequently recognised.

Various mineral species were identified in most of the exploitation tailings and associated outcrops. When (argentiferous) galena is very abundant in dumps, silver/lead exploitation is hypothesised. Similarly, iron mining is presumed in areas exceptionally rich in pyrite or iron oxide. Locally, cassiterite, tennantite or tetrahedrite were recognised, which might suggest tin and copper mining. Some auriferous arsenopyrite was also occasionally found. In addition to the high diversity of minerals found, the situation is complicated by the fact that most of these sites may have experienced polymetallic exploitation, possibly operating in several successive phases. Despite these difficulties, the nature of the exploited metals was ascertained for 39 sites (out of the original 109), including 20 sites with lead (and possibly silver) mining and 15 sites where iron was primarily exploited (Fig. 1f). Both $\mathrm{Mn}$ and As are known to have been mined with more or less success in at least two places. The final two sites were presumed to be $\mathrm{Cu}$ mines. This attribution, which is essential for the remainder of the study, was made with a relatively high level of confidence, either when the field evidence was clear, or better still, when textual archives provided valuable technical details (see Delfour et al., 1991; Gourault, 1999, 2009; Gourault et al., 2012; Tamas, 2004, and references cited therein). The nature of the mineral substances exploited could not be determined, or even suggested, with reasonable confidence for the remaining 70 sites, because no ores were found, or because no particular mineralogical species dominated in dumps (Fig. 1g). No relationship was observed between the types of structures and the nature of the mineral substances exploited. Although no systematic pedestrian prospection was undertaken throughout the entire park (area A2), known mines are included in Fig. $1 \mathrm{f}-\mathrm{g}$. 


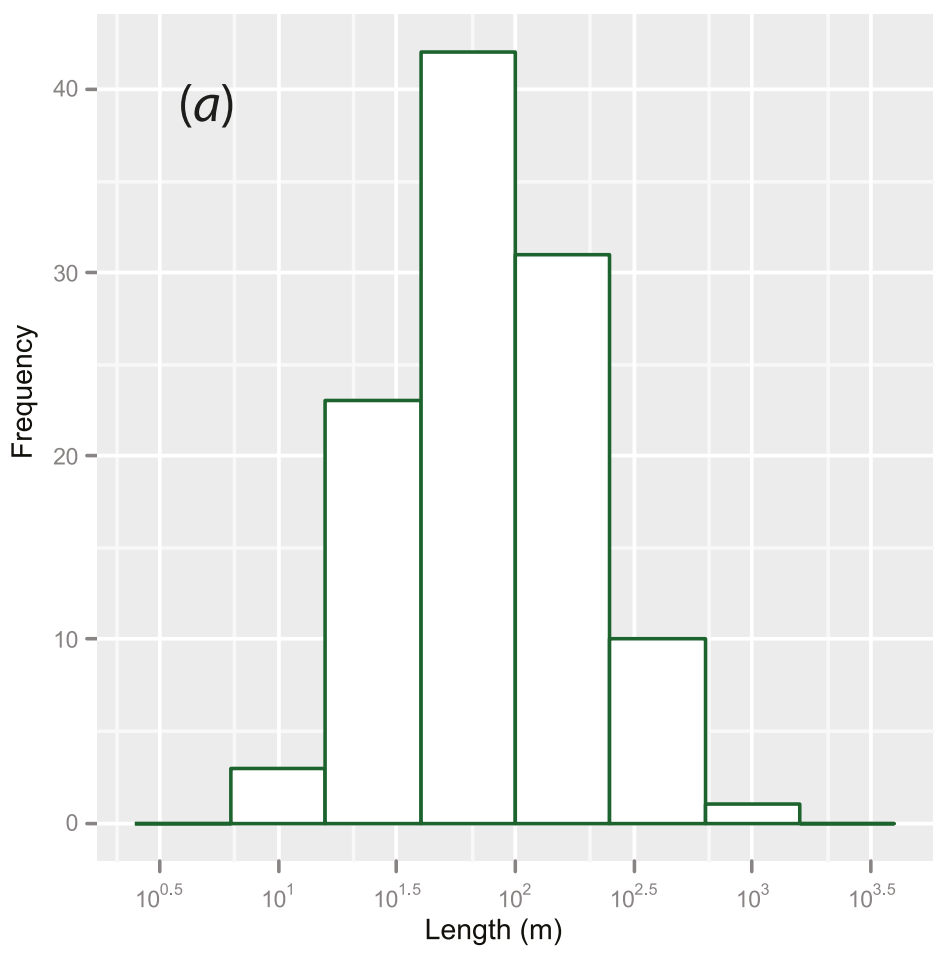

(b)

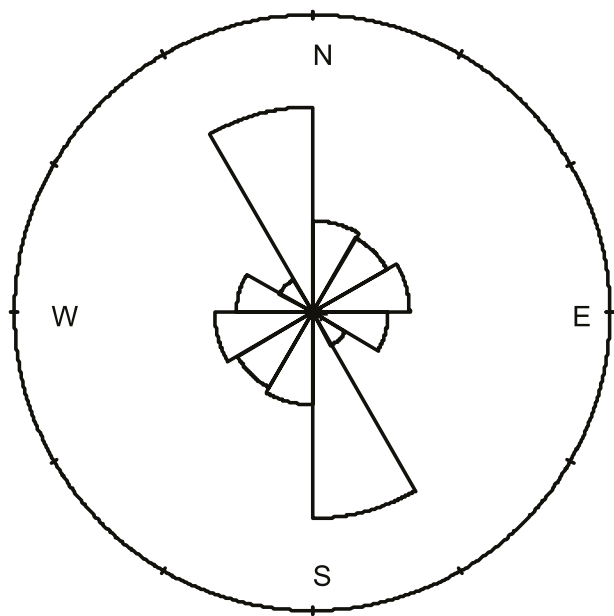

Fig. 4. (a) length frequency distribution of the 110 trenches; note that the $X$-axis is represented with a logarithmic scale; (b) orientation of trenches.

\subsection{Geochemical data of stream sediments}

Concentrations in $\mathrm{Pb}, \mathrm{Zn}, \mathrm{Cu}, \mathrm{As}, \mathrm{Fe}_{2} \mathrm{O}_{3}$ and $\mathrm{MnO}$ for the streambed sediments collected in the pilot area vary widely, as shown in Table 2. They can reach high values, as for instance almost $1200 \mathrm{mg} \mathrm{kg}^{-1}$ for $\mathrm{Pb}$, and $1300 \mathrm{mg} \mathrm{kg}^{-1}$ for As. When concentrations were below the limit of detection (LOD), it was decided to affect values corresponding to $75 \%$ of the LOD, as usually applied (Baxter, 2003). As expected, skewness for $\mathrm{Pb}, \mathrm{Zn}, \mathrm{Cu}, \mathrm{As}$, and $\mathrm{MnO}$ is very positive, revealing asymmetric right-tailed distributions. Once log-transformed, the data tend to be more compatible with normal law, as shown by changes in skewness. However, the original $\mathrm{Fe}_{2} \mathrm{O}_{3}$ distribution does not strongly differ from the normal model.

\subsection{Evaluating EDA- and fractal-based prospectivity maps on the pilot area}

EDA- and fractal-based prospectivity maps are displayed in Figs. 5 and 6, respectively (see also Table 3 for the values of the fractal-based thresholds). Interestingly, both methods produce very similar maps for $\mathrm{Fe}, \mathrm{Mn}, \mathrm{Zn}$, and to a lesser extent for $\mathrm{Pb}$. For this latter element, a notable difference is the presence of an anomalous area situated in the NW of the EDA map (Fig. 5), which is not so clearly depicted by the fractal analysis (Fig. 6). Although comparable, $\mathrm{Cu}$ and As maps exhibit different degrees of anomaly demarcation: EDA procedure delineates more anomalous areas for $\mathrm{Cu}$ than the $\mathrm{C}-\mathrm{A}$ method, whereas the situation is reversed for As. These discrepancies probably result from the difficulty of establishing clear thresholds for $\mathrm{Cu}$ and As from their respective $\mathrm{C}-\mathrm{A}$ plots. Most of the anomalies occur along a corridor oriented NESW, which is clearly depicted by the EDA point pattern (see Fig. 5, left part, for $\mathrm{Cu}, \mathrm{Pb}$ and $\mathrm{Zn}$ ). This corridor essentially corresponds to sedimentary and volcano-sedimentary formations (Fig. 1e). In any case, the anomalies identified cannot be explained by modern industrial and/or urban effluents, as the areas concerned are very sparsely inhabited (Fig. 1d), and almost free from polluting anthropogenic activities. As the spatial distributions of Mn and Fe are not correlated, it is likely that $\mathrm{Cu}, \mathrm{Pb}$ and $\mathrm{Zn}$ anomalies cannot only be driven by scavenging of $\mathrm{Mn}$ - and Fe-oxides. A more obvious explanation should be sought from $(i)$ natural metal enrichments, possibly due to the presence of ore bodies, combined or not with (ii) mechanical erosion or leaching of slag heaps, workshop grounds, and cleansing dumps, which may durably contaminate the aquatic environment, long after mining has ceased, as already demonstrated elsewhere in the Massif Central (Monna et al., 2011).

Table 2

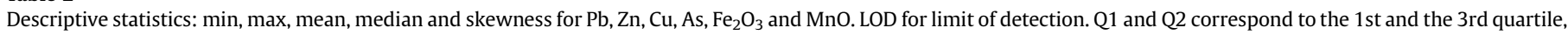
respectively. Between parenthesis, the skewness after log-transformation; without transformation otherwise.

\begin{tabular}{|c|c|c|c|c|c|c|}
\hline & $\mathrm{Pb}\left(\mathrm{mg} \mathrm{kg}^{-1}\right)$ & $\mathrm{Zn}\left(\mathrm{mg} \mathrm{kg}^{-1}\right)$ & $\mathrm{Cu}\left(\mathrm{mg} \mathrm{kg}^{-1}\right)$ & As $\left(\mathrm{mg} \mathrm{kg}^{-1}\right)$ & $\mathrm{Fe}_{2} \mathrm{O}_{3}(\%)$ & $\mathrm{MnO}(\%)$ \\
\hline LOD & 10 & 10 & 10 & 20 & 0.1 & 0.01 \\
\hline Min & $<10$ & 20 & $<10$ & $<20$ & 0.4 & 0.01 \\
\hline Q1 & 44 & 79 & 11 & 21 & 2.5 & 0.04 \\
\hline Median & 56 & 102 & 12 & 38 & 3.3 & 0.06 \\
\hline Mean & 72 & 113 & 16.8 & 50.1 & 3.37 & 0.066 \\
\hline Q3 & 76 & 133 & 18 & 61 & 4.1 & 0.08 \\
\hline Max & 1188 & 660 & 516 & 1305 & 15 & 0.65 \\
\hline Skewness & $7.0(1.36)$ & $2.8(0.27)$ & $10.7(1.3)$ & $9.0(0.45)$ & $0.87(-0.63)$ & $3.64(-0.08)$ \\
\hline
\end{tabular}



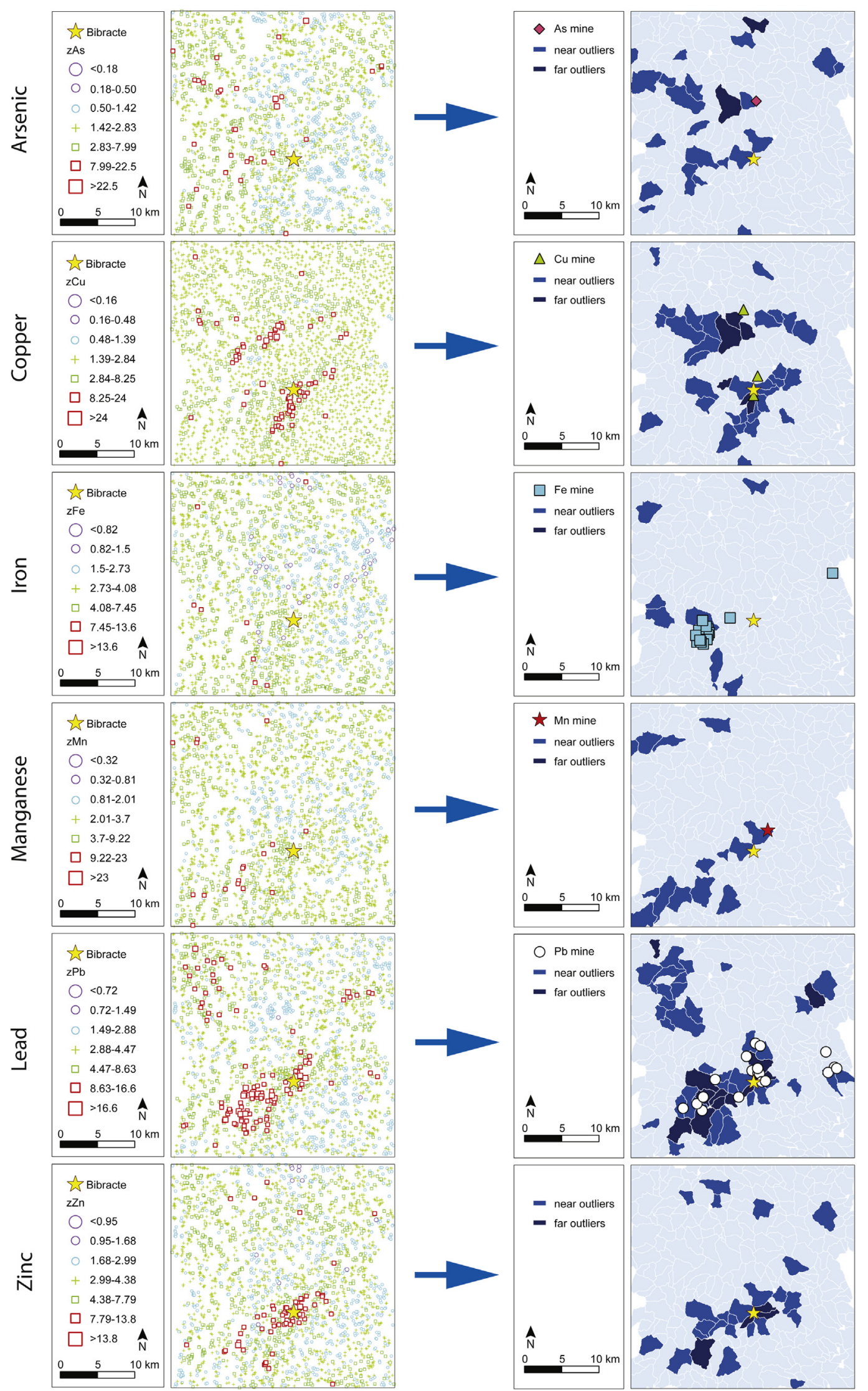

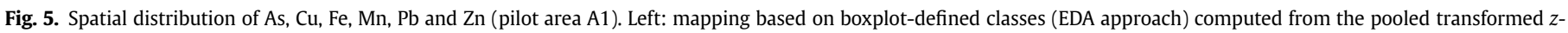
pooled $(i)$ values $(\mathrm{i}=\mathrm{As}, \mathrm{Cu}, \mathrm{Fe}, \mathrm{Mn}, \mathrm{Pb}, \mathrm{Zn})$. Right: mapping based on catchment basin polygons; only the near and far positive outliers are considered. 

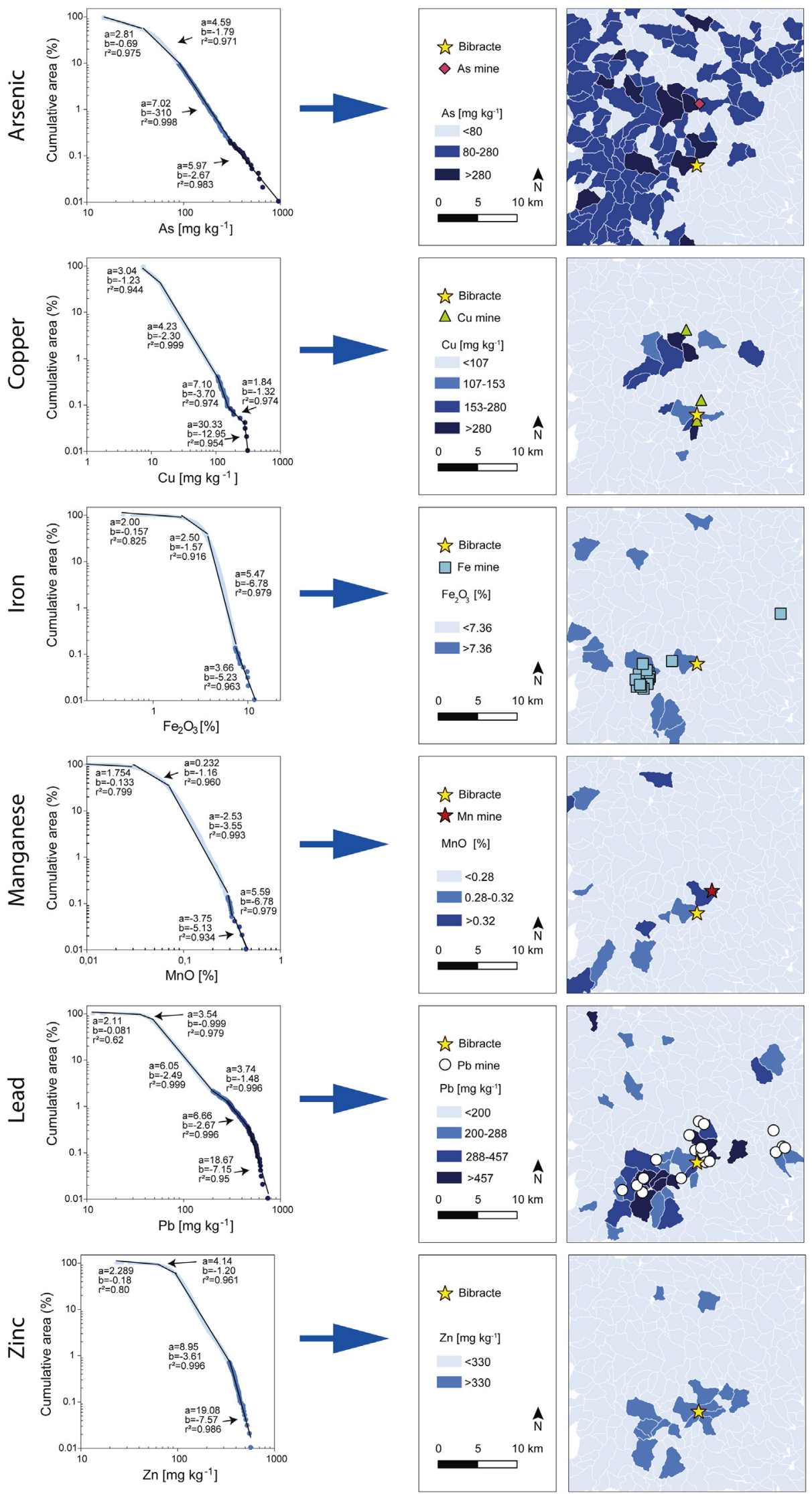

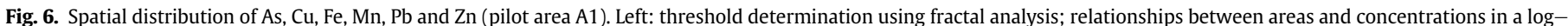

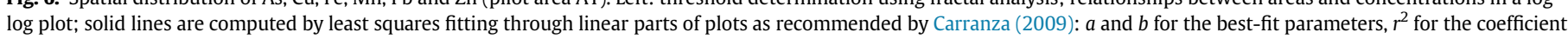

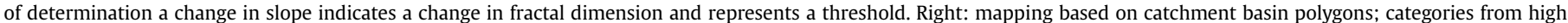
background and above are considered. 
Table 3

Interpretation of ranges based on thresholds defined by concentration-area fractal analysis for the pilot area (A1). The background values are highlighted in bold.

\begin{tabular}{|c|c|c|c|c|c|c|}
\hline Range & As $\left(\mathrm{mg} \mathrm{kg}^{-1}\right)$ & $\mathrm{Cu}\left(\mathrm{mg} \mathrm{kg}^{-1}\right)$ & $\mathrm{Fe}_{2} \mathrm{O}_{3}(\%)$ & $\mathrm{MnO}(\%)$ & $\mathrm{Pb}\left(\mathrm{mg} \mathrm{kg}^{-1}\right)$ & $\mathrm{Zn}\left(\mathrm{mg} \mathrm{kg}^{-1}\right)$ \\
\hline Very low background & - & - & $\leq 2$ & $\leq 0.03$ & $\leq 35$ & $\leq 64$ \\
\hline Low background & $\leq 35$ & $\leq 14$ & $\overline{2}-3.3$ & $0.03-0.07$ & $35-47$ & $\overline{6} 4-96$ \\
\hline Background & {$[35$} & $14-107$ & $3.3-7.36$ & $0.07-0.28$ & 47-200 & $96-330$ \\
\hline High background & $-80]$ & $107-153$ & $>7.36$ & $0.28-0.32$ & $200-288$ & $>330$ \\
\hline Low anomaly & $80-280$ & $153-280$ & - & $>0.32$ & $288-457$ & - \\
\hline High anomaly & $>280$ & $>280$ & - & - & $>457$ & - \\
\hline
\end{tabular}

The aim is now to compare the mines found by pedestrian prospection with the prospectivity maps established from geochemical data alone, in order to evaluate the pertinence of these latter for further archaeological prospection. It could have been tempting to separate modern mines (post 18th century) from the ancient ones in the analysis, because knowledge of minerals and exploitation techniques have obviously improved over time. At least in our case, this cannot be done because the number of modern works (excluding $\mathrm{U}, \mathrm{F}$ and Ba exploitations) is too low (See Supplementary Material, mine database for details). Interestingly, when these more recent extraction works started, the presence of anterior works was often discovered. The entire database of mines can therefore be used. It is important to remember that the total surface of the anomalous areas is overestimated because the maximal concentration value was applied within each drainage basin. From an archaeological point-of-view, our working hypothesis is that there is a greater probability of discovering former mines in these "extended" watersheds than in surrounding areas. This hypothesis cannot be formally tested for $\mathrm{Cu}$, As and $\mathrm{Mn}$, because the number of known exploitations of these types within the pilot area is low: only one As mine, mentioned in the archives, 3 supposed $\mathrm{Cu}$ mines, and 1 known Mn exploitation. It is noteworthy however that these mines always occur within or close to watersheds recognised as anomalous (Figs. 5-6, right). Arsenic is generally used as a pathfinder for geochemical exploration, as it may reveal the presence of $\mathrm{Au}, \mathrm{Ag}$ and other precious metals in epithermal and mesothermal deposits (Weissberg, 1969; Henley, 1985). During sub-aerial oxidation, As, a mobile element contained in sulphide ore minerals, is released in surface environments, and may produce anomalous concentration dispersion trends, which help in detecting ore bodies (Hale, 1981). Within the pilot area, arsenic is present at a high level (geometric mean $=37.8 \mathrm{mg} \mathrm{kg}^{-1}$ ), and can reach extremely high concentrations (ca. $1300 \mathrm{mg} \mathrm{kg}^{-1}$ ). For comparison, the median arsenic concentration for streambed sediments in Western Europe is only about $6 \mathrm{mg} \mathrm{kg}^{-1}$ (FOREGS, 2005). Values as high as those measured in the Morvan are therefore generally ascribed to mineralisations and mining activities. Although geologically significant, they probably do not occur in association with Au. Indeed, there is no field evidence of clear Au potential in the Morvan, except some fruitless exploitation attempts, which took place during the early 20th century at Dun-sur-Gandry, near the pilot area (Durante and Durante, 2007). Originally, Au extraction was motivated at that place by one single analysis, which provided exceptionally high gold and silver contents of $52 \mathrm{~g}_{\text {ton }^{-1}}$ in chalcopyrite and $450 \mathrm{~g} \mathrm{ton}^{-1}$ in galena, respectively. Unfortunately, all further complementary works were much less encouraging, leading to the quick and definitive collapse of the company involved in this exploitation (Durante and Durante, 2007). Gold washing in the Morvan rivers is known to be broadly unproductive, or at best marginal, unlike some other places in France where Au has been exploited since Prehistory (Cauuet, 2001, 2004). Although iron mines are mostly located in areas slightly anomalous in iron content, prospectivity mapping is probably not well adapted to the discovery of this kind of activity because $\mathrm{Fe}$, a major constituent of the continental crust, is present at high concentration in a wide variety of environments. As a result, anomalies are difficult to detect in weathering products, such as streambed sediments. Lead offers a much better opportunity of testing the predictability of the maps built. Twenty $\mathrm{Pb}$ mines have been discovered within the pilot area, yielding a suitable dataset for a statistical validation. Prediction-rate diagrams, expressing the percentage of mines discovered as a function of the percentage of areas prospected, can be computed (Fig. 7a-b). At that step, it is important to understand that the true position of mines is not used as guidance for prospection. The geochemical data alone are used, treated in terms of prospectivity maps, starting from the drainage basins with the highest prospectivity scores, and continuing until the very last basin, however low its score. The approach, which consists in comparing the predictive models developed with a complete spatial randomness (CSR) model (Carranza, 2009), where chances of discovery are just accidental, is quite similar to the one proposed in Kvamme (1988, p329) as a "gain" calculation. Expressed in a different way, it is hoped that the percentage of sites within the prospected areas will be much greater than the percentage of areas explored. Whatever the procedure chosen, $\sim 70 \%$ of $\mathrm{Pb}$ mines are discovered by prospecting only $\sim 15-20 \%$ of the whole zone (i.e. the surfaces presenting a mining potential, Fig. $7 a-b)$, and almost all the mines are found by only scanning 50\% of the area. This is statistically much better than a CSR (Kolmogorov-Smirnov test, $p<10^{-6}$ ), and clearly demonstrates the remarkable gain of the proposed approach in terms of time, effort and money saved, for any archaeological prospector. At least for our specific case, the multifractal approach is as powerful as the less sophisticated EDA. Moreover, the good results of this pilot study interestingly demonstrate that past societies discovered and mined the main mineral resources of the area. Before extending the procedures developed here to the entire area of the park, it is worth recalling that both predictive models were not established from supervised pattern recognition, where mine locations are known, while local descriptors (e. g. streambed sediment geochemistry, slope, geology, etc.) are forced to produce a model having good predictive capabilities. Such a supervised approach is efficient when training data (here data from the pilot area) are fully representative of the entire area. In our case, these prerequisites are probably not fulfilled because of the heterogeneity of the study site, in terms of geology and geography (Fig. 1b,c,e). That is why less constraining, unsupervised models were preferred.

\subsection{Extending prospectivity maps to the entire park area (A2)}

The EDA model (including the lithological adjustments as described above) was privileged in the following because (i) it is easier to implement and, (ii) derived thresholds are less subject to interpretation than those obtained by fractal-based analysis (see Figs. 5 and 6). In any case, both procedures produce approximately the same maps for all Morvan Regional Natural Park data (Fig. 8, see 

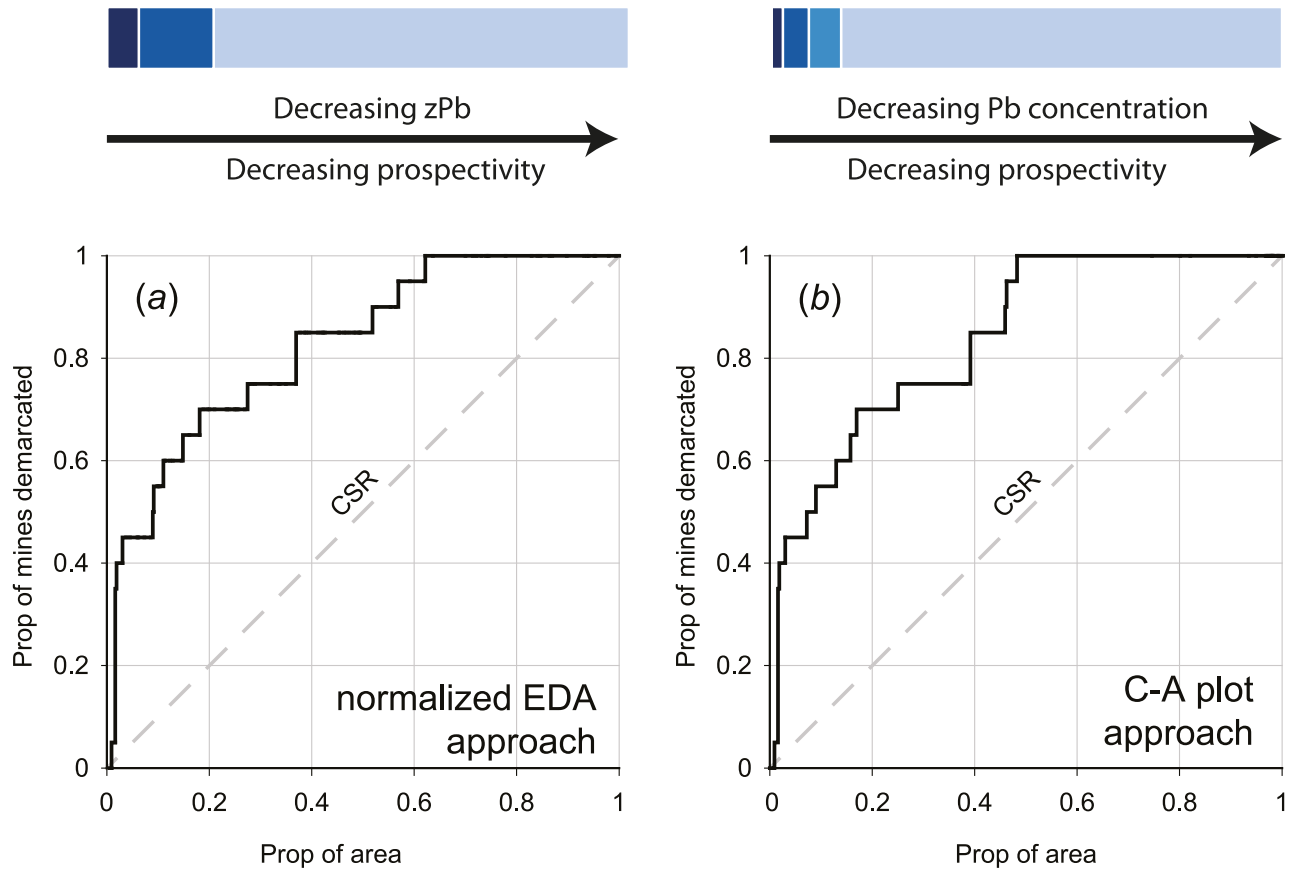

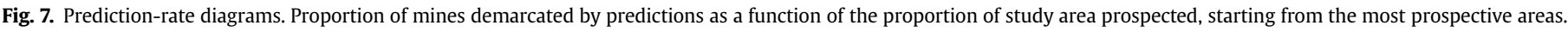

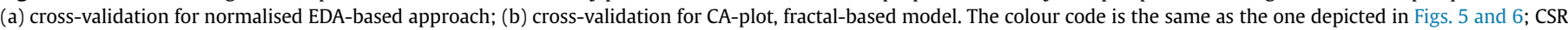
for complete spatial randomness model. (For interpretation of the references to colour in this figure legend, the reader is referred to the web version of this article.)

also Fig. S1 and Table S1 in Supplementary Material for threshold interpretation). When geochemical data are available, attested mines appear in anomalous areas, as for example the lead mine of Alligny-en-Morvan located NE of the park (Fig. 8a), which is known to have been mined sporadically during the 17th, 18th and 20th centuries with more or less success. See also the gold mine of Dunsur-Gandry, discussed above, and located close to the western border of the park (Fig. 8c).
Most of the mines, for which the nature of the minerals exploited is unknown, lie within drainage basins characterised by lead or copper anomalies, or both (Fig. 8a-b). The probability of lead and/or copper mining is therefore high for these sites. Iron extraction, which does not leave any clear fingerprint within the geochemical landscape, must nevertheless not be underestimated. It is probably the most frequent type of mining at the scale of the Morvan massif. Similarly, Sn concentrations, although measured by
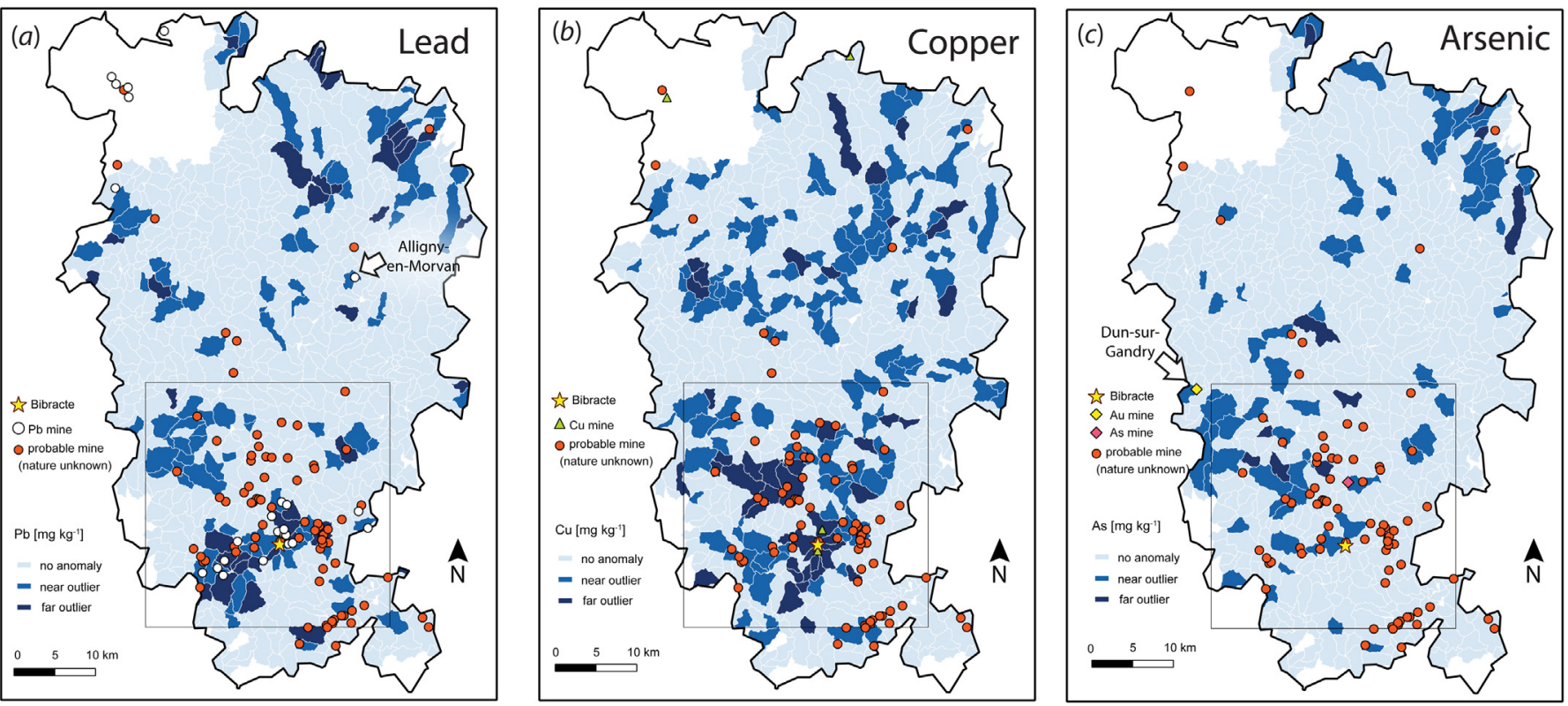

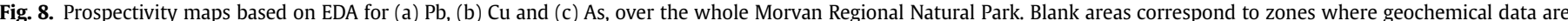

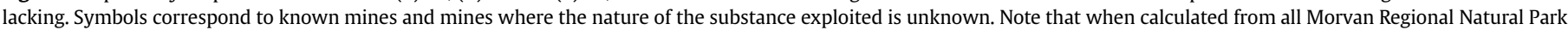
data, the prospectivity maps of the pilot area $\mathrm{Z1}$ are not exactly the same as in Fig. 5, but remain comparable. 
the BRGM, were most of the time below the detection limit, so that possible tin mining was not explored by geochemical mapping in the present study. However, significant alluvial tin mining, including large hydraulic installations, occurred near Autun, located just a few kilometres SE, in a valley bordering the massif (Cauuet et al., 2006).

Many studies have already shown the validity of combining environmental geochemistry and archaeology in various contexts (e.g. Grattan et al., 2007; Mighall et al., 2002, 2009; Breitenlechner et al., 2010; Forel et al., 2010). The present paper confirms that the study of the geochemical imprints left on their environment by former societies working on metals can be mutually enriching for both archaeologists and environmental researchers.

\section{Conclusion}

The tens of thousands of geochemical analyses performed on streambed sediments during the 1970s-1980s to make an inventory of mineral substances can be advantageously exploited today to target areas where former mining may have taken place. In our case, both EDA and fractal-based models produce similar prospectivity maps, which greatly surpass the probability of making any such findings by chance. These results are quite encouraging. Some notable improvements are expected with the use of very high resolution digital elevation models (e.g. LIDAR). Such technology will make possible the delimitation of subwatersheds corresponding to individual samples. In this case, any archaeologist will be able to target much more precisely areas with high prospectivity values. Once mastered, the whole procedure takes at most only a few days, and can therefore save a considerable amount of time, effort and, as a consequence, money for any archaeological prospector working in the field of past mining. Technically, there is no real obstacle to the application of the methodology proposed here as: (i) the software and associated packages are freely available from the web, as well as the original dataset (at least in France), and (ii) the mathematical skills required are basic and easily acquired. Besides favouring the discovery of new sites, the resulting maps may help in better hypothesising the nature of the mineral substances mined, when field or textual evidence is lacking. Obviously the method described here is a first step before a more conventional archaeological investigation, which is necessary to reveal the phases and the techniques of exploitations, the organisation of works and their relationships with populations living nearby, etc. It should also be kept in mind that a positive anomaly is not always accompanied by mining works, either because the area has not been recognised in the past as potentially productive, or because the technical skills needed for exploitation were not available at that time. In contrast, there is little chance of finding mines of any importance in areas characterised by very low prospectivity potential. Interestingly, the oppidum of Bibracte is situated at the centre of an area presenting a high potential for lead and copper, which has been exploited to the utmost. As previously suggested, the attractiveness of mineral resources was probably involved in the installation and development of Aeduan occupation at that particular site.

\section{Acknowledgements}

We are grateful to the Parc Naturel Regional du Morvan, the FEDER ( $\mathrm{n}^{\circ}$ 34328), the Regional Council of Burgundy (grant $n^{\circ}$ 2010-9201AAO50S04060), Centre Archéologique Européen du Mont Beuvray and the University of Burgundy for funding the research. The French Ministry of Research is thanked for the Ph.D. grant of Estelle Camizuli. We wish to thank Claude Gourault and
Gilles Hamm for their implication during the field campaign. We are also grateful to the anonymous reviewers whose judicious comments have improved the manuscript.

\section{Appendix A. Supplementary data}

Supplementary data related to this article can be found at http:// dx.doi.org/10.1016/j.jas.2014.04.022.

\section{References}

Akima, H., 1970. A new method of interpolation and smooth curve fitting based on local procedures. J. Assoc. Comput. Mach. 17, 589-602.

Ambert, P. 1995. Les mines préhistoriques de Cabrières (Hérault) : quinze ans de recherches. État de la question. Bull. Soc. Préhist. Fr. 92, 499-508.

Barge, H., Bourhis, J.-R., Rostan, P., 1998. Métallurgie Préhistorique et gîtes cuprifères dans le sud-est de la France. Premiers résultats. In: d'Anna, A., Binder, D. (Eds.), Production et identité culturelle : Actualité de la recherche : actes de la deuxième session, Arles (Bouches-du-Rhône), 8 et 9 novembre 1996. A.P.D.C.A., pp. 65-80.

Baxter, M., 2003. Statistics in Archaeology. Arnold Applications of Statistics, London, 291 p.

Bonham-Carter, G.F., Goodfellow, W.D., 1986. Background corrections to stream geochemical data using digitized drainage and geological maps: application to Selwyn Basin, Yukon and Northwest Territories. J. Geochem. Explor. 25, 139-155.

Breitenlechner, E., Hilber, M., Lutz, J., Kathrein, Y., Unterkircher, A., Oeggl, K., 2010. The impact of mining activities on the environment reflected by pollen, charcoal and geochemical analyses. J. Archaeol. Sci. 37, 1458-1467.

Bronk Ramsey, C., 2001. Development of the radiocarbon program OxCal. Radiocarbon $43,355-363$. Proceedings of $17^{\text {th }}$ International ${ }^{14} \mathrm{C}$ Conference.

Brown, C.T., Witschey, W.R.T., 2003. 2003. The fractal geometry of ancient Maya settlement. J. Archaeol. Sci. 30, 1619-1632.

Brown, C., Witschey, W., Liebovitch, L., 2005. The broken past: fractals in archaeology. J. Archaeol. Method Theory 12, 37-78.

Carranza, E.J.M., Hale, M., 1997. A catchment basin approach to the analysis of geochemical-geological data from Albay province, Philippines. J. Geochem. Explor. 60, 157-171.

Carranza, E.J.M., 2009. Geochemical Anomaly and Mineral Prospectivity Mapping in GIS. In: Handbook of Exploration and Environmental Geochemistry, vol. 11 Elsevier Ed, $351 \mathrm{p}$.

Carranza, E.J.M., 2011. Analysis and mapping of geochemical anomalies using logratio-transformed stream sediment data with censored values. J. Geochem. Explor. 110, 167-185.

Carozza, L., Mille, B., Bourgarit, D., Rostan, P., Burens, A., 2011. Mine et métallurgie en haute montagne dès la fin du Néolithique et le début de l'âge du Bronze: l'exemple de Saint-Véran en Haut-Queyras (Hautes-Alpes, France). In: Proceedings of L'ETÀ DEL RAME IN ITALIA, Istituto di preistoria e protostoria.

Cauuet, B., Boussicault, M., 2006. Sondage d'une minière à la Pâture des Grangerands. In: Rapp. Annu. Act. Sci. Bibracte. Centre Archéologique Européen de Bibracte, Glux-en-Glenne, pp. 129-161.

Cauuet, B., 2001. Mines d'or des Pyrénées dans l'Antiquité. État des connaissances en haute Ariège. In: Les Ressources naturelles des Pyrénées : leur exploitation dans l'antiquité Sablayrolles. Robert Ed, pp. 155-177.

Cauuet, B., 2004. L'or des celtes en limousin. Culture \& Patrimoine en Limousin, Limoges.

Cauuet, B., Tamas, C.G., Guillaumet, J.-P., Petit, C., Monna, F., 2006. Les exploitations minières en pays éduen. Les Doss. l'Archéol. 316, 20-25.

Charleuf, G., 1867. Etude archéologique des sources thermales de Saint- Honoré. Bull. Soc. Nivernaise Lett. Sci. Arts 2, 318-336.

Cheng, Q., Agterberg, F.P., Ballantyne, S.B., 1994. The separation of geochemical anomalies from background by fractal methods. J. Geochem. Explor. 51, 109-130.

Cheng, Q., Agterberg, F.P., Bonham-Carter, G.F., 1996. A spatial analysis method for geochemical anomaly separation. J. Geochem. Explor. 56, 183-195.

Cheng, Q., 1999. Spatial and scaling modelling for geochemical anomaly separation. J. Geochem. Explor. 65, 175-194.

Cicchella, D., De Vivo, B., Lima, A., 2008. Background and baseline concentration values of elements harmful to human health in the volcanic soils of the metropolitan and provincial areas of Napoli (Italy). Geochem. Explor. Environ. Anal. 5, 29-40.

Delfour, J., Arene, J., Clozier, L., Carroue, J.P., Cornet, J., Delance, J.H., Feys, R., Lemiere, B., 1991. Notice explicative, Carte géologique de France (1/50 000), feuille Autun (551). Éd BRGM, Orléans, 88 p.

Deng, J., Wang, Q., Yang, L., Wang, Y., Gong, Q., Liu, H., 2010. Delineation and explanation of geochemical anomalies using fractal models in the Heqing area, Yunnnan Province, China. J. Geochem. Explor. 105, 95-105.

Durante, V., Durante, N., 2007. Un prospecteur en Morvan : V. Gautheron de Coudray. Vents du Morvan 26, 26-31.

FOREGS, 2005. Geochemical Atlas of Europe. Association of the geological surveys of the European Union (EuroGeoSurveys)/the Geological Survey of Finland. http:// www.gtk.fi/publ/foregsatlas/. 
Forel, B., 2009. Approvisionnement et consommation métalliques en France Orientale protohistorique : approches paléo-environnementales et caractérisations chimiques du mobilier métallique (Ph.D. thesis). Université de Bourgogne.

Forel, B., Monna, F., Petit, C., Bruguier, O., Losno, R., Fluck, P., Begeot, C., Richard, H. Bichet, V., Chateau, C., 2010. Historical mining and smelting in the Vosges Mountains (France) recorded in two ombrotrophic peat bogs. J. Geochem. Explor. 107, 9-20.

Garrett, R.G., Reimann, C., Smith, D.B., Xie, X., 2008. From geochemical prospecting to international geochemical mapping: a historical overview. Geochem. Explor. Environ. Anal. 8, 205-217.

Garrett, R.G., 2013. The 'rgr' package for the R Open Source statistical computing and graphics environment - a tool to support geochemical data interpretation. Geochem. Explor. Environ. Anal. 13, 355-378.

Grattan, J.P., Gilbertson, D.D., Hunt, C.O., 2007. The local and global dimensions of metalliferous pollution derived from a reconstruction of an eight thousand year record of copper smelting and mining at a desert-mountain frontier in southern Jordan. J. Archaeol. Sci. 34, 83-110.

Gourault, C., 1999. Géologie des gîtes minéraux du Morvan. SHNA ed, 240 pp.

Gourault, C., 2009. Les anciennes mines du Haut Morvan. Méthode d'inventaire, essai de caractérisation. Mémoire de Master 2, Université de Bourgogne, 117 p. (unpublished).

Gourault, C., Peraud, W., Camizuli, E., Guillaumet, J.-P., Hamm, G., Monna, F., Petit, C., 2012. Minéralogie de la mine du Prabis (Villapourçon, Nièvre, France). Bourgogne Nature 13, pp. 96-116.

Guillaumet, J.-P., Niaux, R., Moreau, R., 2001. Traces d'exploitation de minerai en Morvan. Académie du Morvan 51, pp. 36-40.

Hale, M., 1981. Pathfinder applications of arsenic, antimony and bismuth in geochemical exploration. J. Geochem. Explor. 15, 307-323.

Hassani, H., Daya, A., Alinia, F., 2009. Application of a fractal method relating power spectrum and area for separation of geochemical anomalies from background. Aust. J. Basic Appl. Sci. 3, 3307-3320.

Healy, J.F., 1978. Mining and Metallurgy in the Greek and Roman World. Ed. Thames and Hudson, London.

Henley, R.W., 1985. The geothermal framework of epithermal deposits. In: Berger, B.R., Bethke, P.M. (Eds.), Geology and geochemistry of epithermal systems, Reviews in Economic Geology, vol. 2, pp. 1-24.

Jouffroy-Bapicot, I., Pulido, M., Galop, D., Monna, F., Ploquin, A., Baron, S., Petit, C., Lavoie, M., de Beaulieu, J.-L., Richard, H., 2007. Environmental impact of early palaeometallurgy: pollen and geochemical analysis. Veg. Hist. Archaeobot. 16, 251-258.

Kvamme, K., 1988. Development and testing of quantitative models. In: Judge, W. Sebastian, L. (Eds.), Quantifying the Present and Predicting the Past: Theory, Method and Application of Archaeological Predictive Modeling. US Bureau of Land Management, Department of the Interior, Bureau of Land Management Service Center, Denver, Co, 690 pp.

Lambert, A., 2005. Les données géochimiques de l'Inventaire minier du territoire national. Constitution d'une base de données exhaustive. Rapport final, BRGM 53546-FR, 114 pp.
Li, C., Ma, T., Shi, J., 2003. Application of a fractal method relating concentrations and distances for separation of geochemical anomalies from background. J. Geochem. Explor. 77, 167-175.

Mighall, T.M., Abrahams, P.W., Grattan, J.P., Hayes, D., Timberlake, S., Forsyth, S., 2002. Geochemical evidence for atmospheric pollution derived from prehistoric copper mining at Copa Hill, Cwmystwyth, mid-Wales, UK. Sci. Total Environ. 292, 69-80.

Mighall, T.-M., Timberlake, S., Foster, I.-D.-L., Krupp, E., Singh, S., 2009. Ancient copper and lead pollution records from a raised bog complex in Central Wales, UK. J. Archaeol. Sci. 36, 1504-1515.

Monna, F., Petit, C., Guillaumet, J.-P., Jouffroy-Bapicot, I., Blanchot, C., Dominik, J., Losno, R., Richard, H., Lévêque, J., Chateau, C., 2004. History and environmental impact of mining activity in celtic aeduan territory recorded in a peat bog (Morvan, France). Environ. Sci. Technol. 38, 665-673.

Monna, F., Camizuli, E., Revelli, P., Biville, C., Thomas, C., Losno, R., Scheifler, R., Bruguier, O., Baron, S., Chateau, C., Ploquin, A., Alibert, P. 2011. Wild brown trout affected by historical mining in the Cévennes National Park, France. Environ. Sci. Technol. 45, 6823-6830.

Reimann, C., Filzmoser, P., Garrett, R.G., 2005. Background and threshold: critical comparison of methods of determination. Sci. Total Environ. 346, 1-16.

Reimann, C., Garrett, R.G., 2005. Geochemical background - concept and reality. Sci. Total Environ. 350, 12-27.

Reimann, C., Filzmoser, P. Garrett, R.G., Dutter, R., 2008. Statistical Data Analysis Explained: Applied Environmental Statistics with R. John Wiley \& Sons, Ltd., Chichester, England, $343 \mathrm{pp}$.

Schibler, J., Breitenlechner, E., Deschler-Erb, S., Goldenberg, G., Hanke, K., Hiebel, G., Plogmann, H.H., Nicolussi, K., Marti-Gradel, E., Pichler, S., Schmidl, A. Schwarz, S., Stopp, B., Oeggl, K., 2011. Miners and mining in the Late Bronze Age: a multidisciplinary study from Austria. Antiquity 85, 1259-1278.

Sirugue, D., 2008. Le Morvan, inventaire des paysages et du patrimoine naturel. Bourgogne Nature HS 6, 208 pp.

Tamas, C.-G., 2004. Caractérisation minéralogique des mines anciennes du Morvan (2003-2004). Compte Rendu de bourse postdoctorale, Région Bourgogne, 86 pp.

Tukey, J.-W., 1977. Exploratory Data Analysis. Addison-Wesley Editors, Reading, 688 pp.

Tylecotte, R.F., 1987. The Early History of Metallurgy in Europe. Ed. Longman, London and New York.

Wang, Q., Deng, J., Wang, Y., Sun, X., Wan, L., 2011. Fractal models for estimating local reserves with different mineralization qualities and spatial variations. J. Geochem. Explor. 108, 196-208.

Weissberg, B.G., 1969. Gold-silver ore grade precipitates from New Zealand thermal waters. Econ. Geol. 64, 95-108.

Yusta, I., Velasco, F., Herrero, J.-M., 1998. Anomaly threshold estimation and data normalization using EDA statistics: application to lithogeochemical exploration in Lower Cretaceous Zn-Pb carbonate-hosted deposits, Northern Spain. Appl. Geochem. 13, 421-439. 